\title{
Synthesis of an HIV-1 Integrase Allosteric Site Inhibitor
}<smiles>Cc1c(F)cc(F)c2c1CCCO2</smiles>

A mp not reported

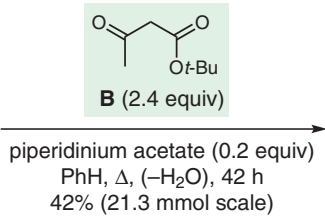
Knoevenagel condensation

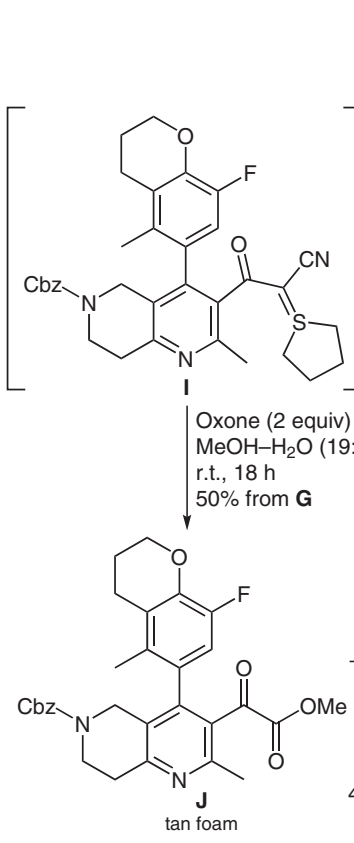

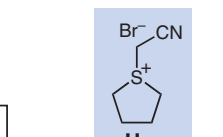
(COCl) $)_{2}(4$ equiv $)$ DMF (0.15 equiv) $\mathrm{CH}_{2} \mathrm{Cl}_{2}, \mathrm{rtt}$,

\section{2. $\mathbf{H}$ (3 equiv)} DIPEA (6 equiv) $\mathrm{CH}_{2} \mathrm{Cl}_{2}$, r.t., $1 \mathrm{~h}$ $4 \mathrm{mmol}$ scale Bode homologation<smiles>CCCCCCCCCC(C)=O</smiles>
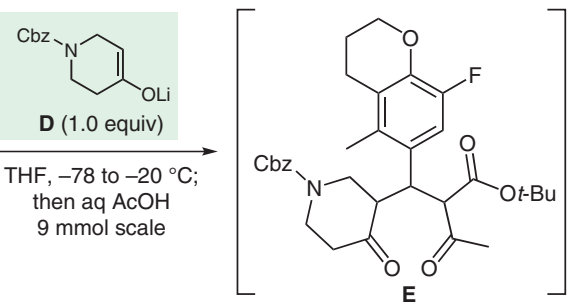

1. $\mathrm{NH}_{4} \mathrm{OAc}$ (10 equiv), $\mathrm{EtOH}, 4,16 \mathrm{~h}$ 2. CAN (2 equiv), $\mathrm{MeOH}$, r.t., $1 \mathrm{~h}$ $47 \%$ from C Hantzsch pyridine synthesis
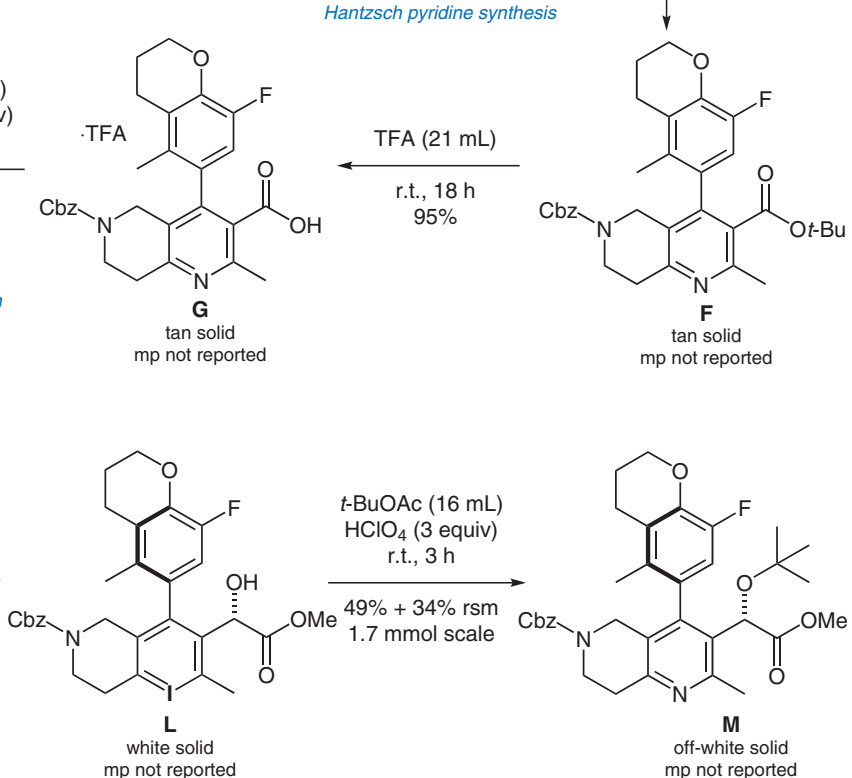
$45 \%$ (4.7 mmol scale) $\mathrm{dr}=1: 1$ Corey-ltsuno reduction<smiles>Cc1ccc(CCCN2CCc3nc(C)c([C@H](OC(C)(C)C)C(=O)O)c(-c4cc(F)c5c(c4C)CCCO5)c3C2)cc1F</smiles>

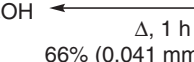
$66 \%(0.041 \mathrm{mmol}$ scale $)$

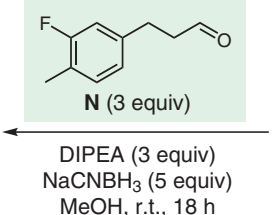

$\mathrm{MeOH}$ r.t. $18 \mathrm{~h}$

\section{Category}

Synthesis of Natural

Products and

Potential Drugs

Key words

5,6,7,8-tetrahydro1,6-naphthyridines

Bode homologation

Corey-Itsuno asymmetric reduction

sulfur ylides

$\alpha$-keto esters
Significance: Tetrahydronaphthyridine $\mathbf{O}$ inhibits HIV-1 integrase, one of the three enzymes encoded in the HIV-1 genome required for viral replication. A markworthy step in the small-scale synthesis depicted is the Bode homologation of carboxylic acid G to $\alpha$-keto ester J via sulfur ylide I (L. Ju, A. R. Lippert, J. W. Bode J. Am. Chem. Soc. 2008, 130, 4253).
Comment: Corey-Itsuno asymmetric reduction of $\alpha$-keto ester J gave a 1:1 mixture of diastereoisomers from which the desired atropisomer $\mathbf{L}$ was isolated in $45 \%$ yield by column chromatography and crystallization. Tetrahydronaphthyridine $\mathbf{F}$ was constructed in four steps in $20 \%$ overall yield using a Hantzsch pyridine synthesis. 